\title{
A NEW OCCURRENCE OF ARGENTOPENTLANDITE AND GOLD FROM THE AU- AG-RICH COPPER MINERALISATION IN THE PALIOMYLOS AREA, SERBOMACEDONIAN MASSIF, CENTRAL MACEDONIA, GREECE
}

\author{
V. MELFOS ${ }^{1}$, M. VAVELIDIS ${ }^{1}$, K. ARIKAS $^{2}$
}

\begin{abstract}
The $\mathrm{Au}-\mathrm{Ag}-\mathrm{Cu}$ mineralisation in the Paliomylos area is associated with quartz segregations and pegmatoids in the form of boudinaged bodies. The $\mathrm{Au}, \mathrm{Ag}$ and $\mathrm{Cu}$ contents in the ore bodies reach $6.8 \mathrm{ppm}, 765 \mathrm{ppm}$ and $0.80 \mathrm{wt} \%$. The ore minerals consist of pyrite, chalcopyrite, sphalerite, pyrrhotite, galena, bismuthinite, argentopentlandite, gersdorffite, cobaltite, aikinite, hessite, native bismuth and gold. Pentlandite contains significant amounts in $\mathrm{Ag}$ (13.15 wt \%), $\mathrm{Au}$ (1.59 wt\%) and PGM, demonstrating a formula of $\mathrm{Fe}_{5.37} \mathrm{Ni}_{2.56} \mathrm{Ag}_{1.03} \mathrm{Ir}_{0.03} \mathrm{~S}_{8.01}$. On the basis of geological, textural and chemical data, the mineralisation in the studied area was formed under high temperatures.
\end{abstract}

KEY WORDS: silver-gold-copper mineralisation; argentopentlandite; gold; fluid inclusions; Serbomacedonian massif; Greece

\section{INTRODUCTION}

Serbomacedonian massif has been recognised as a favourable metallogenetic province for polymetallic, porphyry and skarn type ore deposits as well as for fracture-controlled quartz vein deposits, with significant gold and/or silver concentrations (Vavelidis 1994). Mineral exploration and mining activity of these deposits for precious and base metals, date back to the ancient times due to their economic potential (Wagner et al. 1986, Kiourtzoglou et al. 2001).

A detailed investigation concerning the mineral deposits in the broader area of Thessaloniki and Kilkis districts in northern Greece, revealed a significant Au-Ag-rich copper mineralisation in the Paliomylos area. The Paliomylos area is situated close to the villages Stefania, Lefkochorio and Karteres, $35 \mathrm{~km}$ northern of Thessaloniki city and geologically belongs to the Serbomacedonian massif.

The present work aims at studying the sulphide mineralogy and chemistry of the Au-Ag-Cu-bearing mineralisation. Emphasis is given to the chemical composition of the silver minerals, especially to the $\mathrm{Ag}$-bearing pentlandite and to the primary gold chemistry. An attempt to provide data for genetic consideration is based on the fluid inclusion study.

\section{GEOLOGICAL SETTING}

According to the most recent studies, the Serbomacedonian massif is considered to be the western extension of thrust units belonging to the Rhodope metamorphic core complex (Ricou et al. 1998). It is subdivided into two series: the underlying Kerdilion series to the east and the overlying Vertiskos series to the west (Kockel et al. 1977). The rocks of the investigated area have a complicated petrotectonic history (Dixon and Dimitriadis 1987, Sakelariou 1989, Kourou 1991, Sidiropoulos 1991, Burg et al. 1995, Kostopoulos et al. 2001) and consist of ortho- and para-gneisses, schists and amphibolites, which belong to the Vertiskos series, as well as ultrabasic rocks (Figure 1). A two-mica and/or biotite granite (of Arnea type) intrudes the Lower Vertiskos sequence. Pliocene to Pleistocene sediments and Quaternary alluvial deposits overlie the older rocks.

Recent zircon $\mathrm{Pb}-\mathrm{Pb}$ dating, performed by Kostopoulos et al. (2001), revealed an Early Middle Ordovician intrusion of the Vertiskos orthogneisses, as well as Late Triassic migmatitisation of these rocks. Geochronological data from the Arnea-type granite, presented by Kostopoulos et al. (2001), yielded an intrusion zircon $\mathrm{Pb}-\mathrm{Pb}$ age of Late Triassic, which compares well with the zircon U-Pb age of Vital (1986). De Wet (1989) demonstrated a

1. Department of Mineralogy, Petrology, Economic Geology, Faculty of Geology, Aristotle University of Thessaloniki, GR-54006, Thessaloniki, Greece.

2. Mineralogisch-Petrographisches Institut, Universitðt Hamburg, D-20146, Hamburg, Germany

*: melfosv@geo.auth.gr 
minimum Late Jurassic age (phengite Ar-Ar data) for the Arnea granite, corresponding probably to mixed age between igneous formation and later deformation. An Early Cretaceous underthrusting of the Vertiskos sequence at depths $11-14 \mathrm{~kb}$ and temperatures of $500-600{ }^{\circ} \mathrm{C}$, is suggested by Kostopoulos et al. (2001).

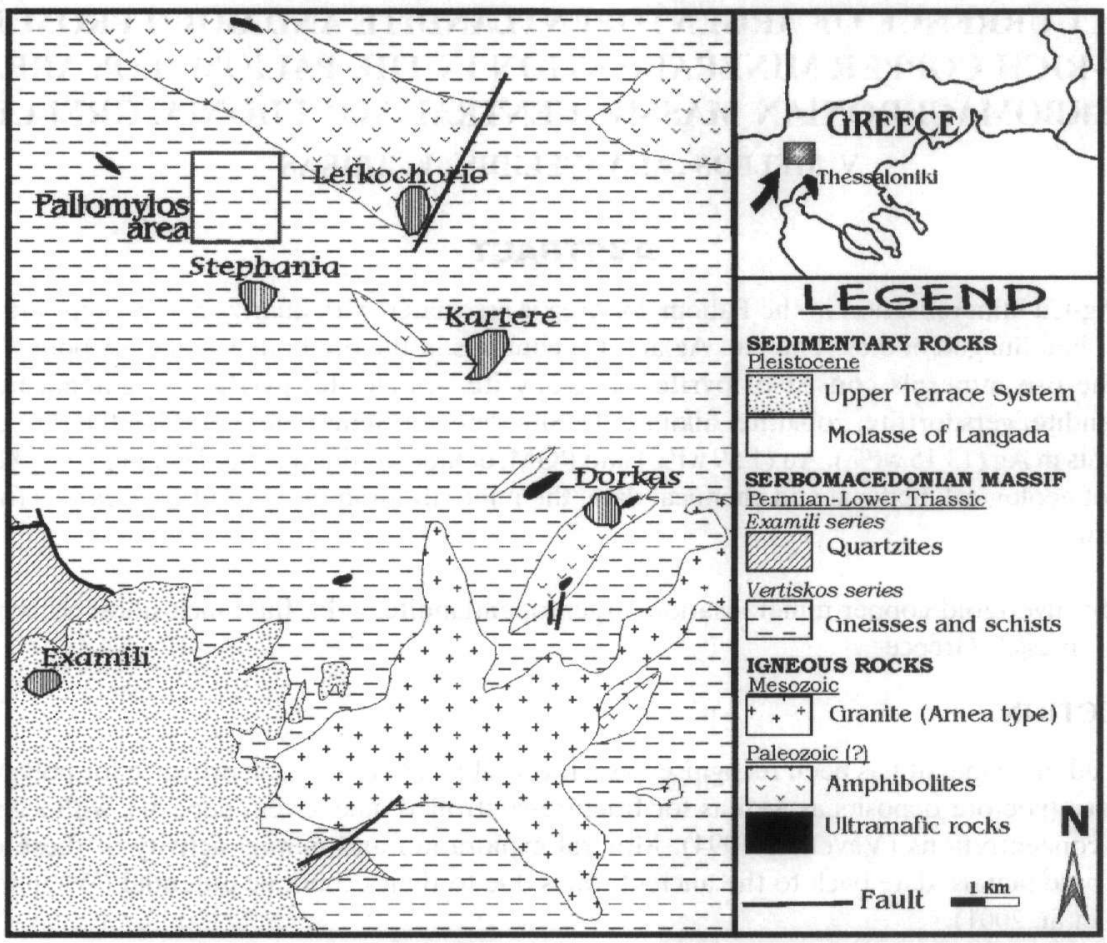

Figure 1. Geological sketch map of the broader area of the Paliomylos Au-Ag-Cu mineralisation.

\section{ANALYTICAL METHODS}

Polished sections of the ore minerals were systematically studied for gold- and silver-bearing minerals and sulphides using reflected light microscopy. Scanning electron microscopy was performed on a JEOL JSM 840 at the Department of Mineralogy, Petrology, Economic Geology, University of Thessaloniki. Ore and rock wholesamples were analyzed by ICP at ACME Analytical Laboratories, Vancouver, Canada. Microprobe analyses were carried out by a Cameca Camebax Microbeam electron microprobe at the Institute of Mineralogy and Petrology of Hamburg, Germany. The conditioons were $20 \mathrm{kv}$ and $20 \mathrm{nA}$, beam diameter $<1 \mu \mathrm{m}$. Corrections were applied using the Cameca Computer program PAP. Microthermometric measurements on fluid inclusions were carried out on doubly polished thin sections at the Department of Mineralogy-Petrology-Economic Geology, University of Thessaloniki, using a LINKAM THM-600 heating-freezing stage. The equipment is suitable for temperature measurements between $-180^{\circ} \mathrm{C}$ and $600^{\circ} \mathrm{C}$. Calibration was performed using the following melting point standards: chloroform $\left(-63.5^{\circ} \mathrm{C}\right)$, distilled $\mathrm{H}_{2} \mathrm{O}\left(0^{\circ} \mathrm{C}\right)$, naphtalene $\left(80.35^{\circ} \mathrm{C}\right)$, Merck $135\left(135^{\circ}\right.$ $\mathrm{C})$, sacharine $\left(228^{\circ} \mathrm{C}\right)$ and Merck $247\left(247^{\circ} \mathrm{C}\right)$.

\section{ORE MINERALOGY AND TEXTURAL FEATURES}

Systematic field working in the Paliomylos area revealed $\mathrm{Au}-\mathrm{Ag}-\mathrm{Cu}-$ bearing quartz segregations and pegmatoids in the form of boudinaged bodies, with a thickness reaching up $2.30 \mathrm{~m}$ and a length exceeding over $20 \mathrm{~m}$ (Fig. 2a). Structural analyses showed that both quartz segregations and pegmatoids are developed in a NW-SE direction. They are variously deformed and demonstrate a schistosity which is parallel to the dominant schistosity of the host rocks dipping towards NE $\left(20^{\circ}-50^{\circ}\right)$ with a low angle $\left(20^{\circ}-40^{\circ}\right)$. A characteristic structural feature of the host metamorphic rocks as well as the quartz segregations and pegmatoids is the presence of kinkfolds, overprinting the dominant ductile fabric with NW-SE b-axis $\left(» 320^{\circ} / 65^{\circ}\right)$. The metamorphic rocks and the mineralised quartz bodies are crosscut by quartz veins, up to $30 \mathrm{~cm}$ in thickness, which are mineralisation free. 

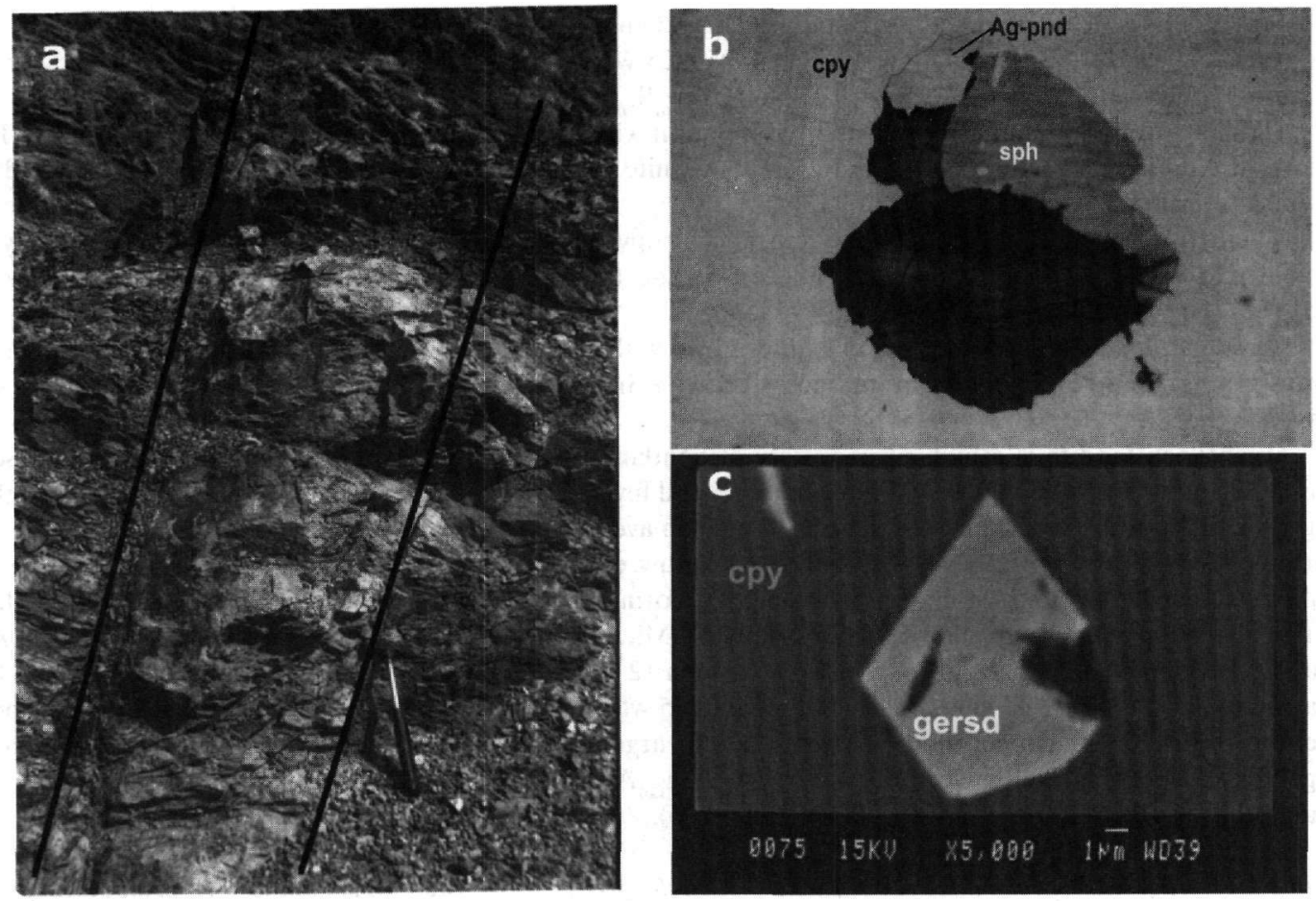

Figure 2. a. Au-Ag-Cu-bearing quartz segregation hosted in the metamorphic rocks of Vertiskos series, Paliomylos area.

b. Argentopentlandite (Ag-pnd) intergrown with sphalerite (sph) within chalcopyrite (cpy). Polished section, //N, picture length $=0.4 \mathrm{~mm}$.

c. Euhedral gersdorffite (gersd) within chalcopyrite (cpy). SEM, back scattering image, polished section.

Chemical analyses of the host metamorphic rocks, carried out by ICP, showed elemental composition 0.130.17 wt \% Fe, 0.02-0.12 wt\% Cu, 28-35 ppm Pb, 40-48 ppm Zn, 138-173 ppm Ag and 530-850 ppb Au. The ore bodies contain significant $\mathrm{Au}$ and $\mathrm{Ag}$ concentrations, reaching $6.80 \mathrm{ppm}$ and $765 \mathrm{ppm}$, respectively. The bulk composition of the ore bodies is up to $16.50 \mathrm{wt} \% \mathrm{Fe}, 0.80 \mathrm{wt} \% \mathrm{Cu}, 0.12 \mathrm{wt} \% \mathrm{~Pb}, 0.46 \mathrm{wt} \% \mathrm{Zn}$ and $0.18 \mathrm{wt} \% \mathrm{As}$.

The ore minerals consist of pyrite, chalcopyrite, sphalerite, pyrrhotite, galena, argentopentlandite, bismuthinite, native bismuth, gersdorffite, cobaltite, aikinite, hessite and native gold, together with quartz as gangue mineral.

Pyrite is volumetrically the most important sulphide of the mineralisation and occurs as disseminated euhedral, subhedral and anhedral crystals of $5 \mu \mathrm{m}$ to $3 \mathrm{~mm}$ in size. The microprobe analyses (Table 1) showed 0.05 to 2.30 wt $\% \mathrm{Co}$ and 0.02 to $1.20 \mathrm{wt} \% \mathrm{Ni}$. The $\mathrm{Co} / \mathrm{Ni}$ ratios vary from 0.60 to 5.10 (3.75 in average). The average chemical composition of pyrite is $\mathrm{Fe}_{0.98} \mathrm{Co}_{0.02} \mathrm{Ni}_{0.01} \mathrm{~S}_{1.99}$.

Chalcopyrite is one of the main minerals present and is found mainly as anhedral grains, intergrown with pyrite and pyrrhotite. In some cases chalcopyrite replaces pyrite along fractures. The characteristic feature of chalcopyrite is the development of inversion-twin lamellae. It also contains inclusions of argentopentlandite and Ag-tellurides (Figure 2b,c). Microprobe analyses in chalcopyrite revealed a stoichiometric composition with Ag content up to $0.15 \mathrm{wt} \%$ ( $0.08 \mathrm{wt} \%$ on average) (Table 1$)$.

Pyrrhotite occurs as inclusions in chalcopyrite, as well as intergrown crystals with sphalerite and chalcopyrite.

Galena and sphalerite are accessory minerals of the copper mineralisation in Paliomylos area. Both minerals are intergrown with pyrite, pyrrhotite and chalcopyrite. Microprobe analyses (Table 1) showed that galena contains up to $0.10 \mathrm{wt} \% \mathrm{Ag}$ and the average chemical formula is $\mathrm{Pb}_{0.99} \mathrm{~S}_{1.01}$. Sphalerite is characterised by relatively high contents of $\mathrm{Fe}$ and $\mathrm{Cd}$, up to $5.80 \mathrm{wt} \%$ and $2.30 \mathrm{wt} \%$, respectively and its average chemical composition is $\mathrm{Zn}_{0.90} \mathrm{Fe}_{0.08} \mathrm{Cd}_{0.01} \mathrm{~S}_{1.01}$.

Bismuth minerals are represented by bismuthinite and native bismuth, which are found as inclusions within 
chalcopyrite in the form of euhedral crystals reaching $35 \mu \mathrm{m}$ in size. Bismuthinite contains $\mathrm{Cu}(0.49-0.63 \mathrm{wt} \%)$, $\mathrm{Ag}(0.11-0.28 \mathrm{wt} \%), \mathrm{Pb}(0.43-0.89 \mathrm{wt} \%), \mathrm{Fe}(0.06-0.25 \mathrm{wt} \%), \mathrm{Te}(0.15-0.40 \mathrm{wt} \%)$ (Table 1$)$, and its average chemical composition is $\mathrm{Bi}_{1.91} \mathrm{Cu}_{0.04} \mathrm{~Pb}_{0.02} \mathrm{Fe}_{0.01} \mathrm{Ag}_{0.01} \mathrm{Te}_{0.01} \mathrm{~S}_{3.00}$.

Aikinite is found within chalcopyrite in association with bismuthinite and in some cases with hessite. The size of the grains ranges between 4 and $25 \mu \mathrm{m}$. Aikinite contains $0.42 \mathrm{wt} \% \mathrm{Ag}$ in average (Table 1) and its chemical formula is $\mathrm{Cu}_{0.94} \mathrm{Ag}_{0.02} \mathrm{Fe}_{0.05} \mathrm{~Pb}_{1.00} \mathrm{Bi}_{0.98} \mathrm{~S}_{3.00}$.

Cobaltite occurs as small euhedral crystals in chalcopyrite, with a size of up to $40 \mu \mathrm{m}$. Microprobe analyses revealed $1.75 \mathrm{wt} \% \mathrm{Ni}$ and $4.70 \mathrm{wt} \% \mathrm{Fe}$ in average (Table 1). The chemical formula of cobaltite is $\mathrm{Co}_{0.84} \mathrm{Fe}_{0.14} \mathrm{Ni}_{0.05} \mathrm{As}_{0.95} \mathrm{~S}_{1.02}$.

Gersdorffite is mainly euhedral and is intergrown with chalcopyrite. A zonal growth has been observed in some grains (Figure 2c). Fe contents are $2.08 \mathrm{wt} \%$ in average (Table 1) and the chemical formula is $\mathrm{As}_{1.01} \mathrm{Ni}_{0.95} \mathrm{Fe}_{0.06} \mathrm{~S}_{0.98}$.

Argentopentlandite is a high-silver variety of pentlandite and has so far been identified as an accessory mineral in a few sulphide deposits in the world. Several investigations, during the last 30 years, have shown that argentopentlandite is a discrete mineral phase, with an average composition of $\left(\mathrm{Fe}_{5} \pm_{0.77} \mathrm{Ni}_{3} \pm_{0.75}\right)_{28} \pm \mathrm{Ag}_{1} \pm \mathrm{S}_{8} \pm$ with $0<[\mathrm{x}]<0.30,0<[\mathrm{y}]<0.23$ and $0<[\mathrm{z}]<0.30$ (Kontny et al. 1994, Morales and Fenoll Hach-Alv 1996). In Paliomylos area it is found within chalcopyrite in the form of small reddish-brown anhedral crystals or patches, with a size ranging between 5 and $65 \mu \mathrm{m}$ (Figure $2 \mathrm{~b}$ ). Microprobe analyses revealed significant amounts in $\mathrm{Ag}$, $\mathrm{Au}$ and PGM (Table 2). The Ag content vary between 12.78 and $13.50 \mathrm{wt} \%$ (13.15 wt\% on average), while the maximum $\mathrm{Au}, \mathrm{Pt}$ and $\mathrm{Ir}$ contents reach $1.59 \mathrm{wt} \%, 0.65 \mathrm{wt} \%$ and $0.85 \mathrm{wt} \%$, respectively. This is the first documented report so far concerning PGM contents in argentopentlandite. The average chemical formula of argentopentlandite in Paliomylos area is $\mathrm{Fe}_{5.44} \mathrm{Ni}_{2.47} \mathrm{Ag}_{1.01} \mathrm{Au}_{0.01} \mathrm{Ir}_{0.01} \mathrm{Pt}_{0.01} \mathrm{~S}_{8.05}$, which agrees with the general formula proposed by Morales and Fenol Hach-Alv (1996).

Table 1. Average microprobe analyses of pyrite (1), chalcopyrite (2), galena (3), sphalerite (4), bismuthinite (5), aikinite (6), cobaltite (7), gersdorffite (8), hessite (9), gold in pyrite (10) and gold in quartz (11) from the AuAg-rich copper mineralisation in the Paliomylos area. bdl=below detection limit

\begin{tabular}{|c|c|c|c|c|c|c|c|c|c|c|c|}
\hline Wto & 1 & 2 & 3 & 4 & 5 & 6 & 7 & 8 & 9 & 10 & 11 \\
\hline $\mathrm{Bi}$ & bdl & bdl & bdl & bdl & 78.89 & 35.52 & bdl & bdl & $\mathrm{bdl}$ & bdl & bdl \\
\hline $\mathrm{Pb}$ & bdl & bdl & 86.32 & bdl & 0.89 & 35.89 & bdl & bdl & 0.08 & bdl & bdl \\
\hline $\mathrm{Au}$ & bdl & bdl & bdl & bdl & bdl & bdl & bdl & bdl & bdl & 82.65 & 97.06 \\
\hline Pt & bdl & bdl & bdl & bdl & bdl & bdl & bdl & bdl & bdl & bdl & bdl \\
\hline Ir & bdl & bdl & bdl & bdl & bdl & bdl & bdl & bdl & bdl & bdl & bdl \\
\hline $\mathrm{Te}$ & bdl & bdl & bdl & bdl & 0.23 & bdl & bdl & bdl & 36.80 & bdl & bdl \\
\hline $\mathrm{Sb}$ & bdl & bdl & bdl & bdl & bdl & bdl & bdl & bdl & bdl & bdl & bdl \\
\hline $\mathrm{Cd}$ & bdl & bdl & bdl & 1.74 & bdl & bdl & bdl & bdl & bdl & bdl & bdl \\
\hline $\mathrm{Ag}$ & bdl & 0.08 & 0.08 & 0.05 & 0.16 & 0.42 & bdl & bdl & 62.65 & 17.26 & 2.71 \\
\hline $\mathrm{Pd}$ & bdl & bdl & bdl & bdl & bdl & bdl & bdl & bdl & bdl & bdl & bdl \\
\hline $\mathrm{Rh}$ & bdl & bdl & bdl & bd1 & bdl & bdl & bdl & bdl & bdl & bdl & bdl \\
\hline $\mathrm{Ru}$ & bdl & bdl & bdl & bd1 & bdl & bdl & bdl & bdl & bdl & bdl & bdl \\
\hline $\mathrm{Se}$ & 0.05 & bdl & bdl & bd1 & bdl & bdl & bdl & bdl & bdl & bdl & bdl \\
\hline As & bdl & bdl & bdl & bd1 & bdl & bdl & 43.35 & 45.38 & bdl & bdl & bdl \\
\hline $\mathrm{Zn}$ & bdl & bdl & bdl & 59.92 & bdl & bdl & bdl & bdl & bdl & bdl & bdl \\
\hline $\mathrm{Cu}$ & bdl & 34.25 & bdl & 0.05 & 0.50 & 10.35 & bdl & bdl & 0.12 & 0.23 & 0.16 \\
\hline $\mathrm{Ni}$ & 0.32 & bdl & bdl & bdl & bdl & bdl & 1.75 & 33.55 & bdl & bdl & bdl \\
\hline Co & 1.20 & bdl & bdl & bdl & bdl & bdl & 30.25 & 0.25 & bdl & bdl & bdl \\
\hline $\mathrm{Fe}$ & 45.40 & 30.58 & bdl & 4.32 & 0.12 & 0.52 & 4.70 & 2.08 & bdl & bdl & bdl \\
\hline Mn & bdl & bdl & bdl & 0.10 & bdl & bdl & bdl & bdl & bdl & bdl & bdl \\
\hline $\mathrm{S}$ & 52.75 & 34.89 & 13.57 & 33.11 & 18.97 & 16.65 & 19.85 & 18.85 & bdl & bdl & bdl \\
\hline Tot & 99.72 & 99.80 & 99.97 & 99.29 & 99.76 & 99.35 & 99.90 & 100.11 & 99.65 & 100.14 & 99.93 \\
\hline
\end{tabular}

Hessite is found within chalcopyrite, intergrown with bismuth minerals and in some cases with galena. The size of hessite grains ranges between 2 and $25 \mu \mathrm{m}$. According to the microprobe analyses (Table 1) the average chemical formula is $\mathrm{Ag}_{2.00} \mathrm{Cu}_{0.01} \mathrm{Te}_{0.99}$

Gold occurs within pyrite and in some cases in quartz. The grain size ranges from 5 to $480 \mu \mathrm{m}$. Gold grains hosted in pyrite are characterised by high $\mathrm{Ag}$ content ranging between 16.25 and $18.25 \mathrm{wt} \%$ (17.26 wt\% on average), whereas gold in quartz contains lower $\mathrm{Ag}$ ( 2.15 to $3.25 \mathrm{wt} \%, 2.71$ on average). Copper is generally low and in both cases does not exceed $0.57 \mathrm{wt} \%$. Based on the analytical results (Table 1), the chemical formula of gold in pyrite is $\mathrm{Au}_{0.72} \mathrm{Ag}_{0.27} \mathrm{Cu}_{0.01}$ and in quartz is $\mathrm{Au}_{0.95} \mathrm{Ag}_{0.05}$. 
Table 2. Selected microprobe analyses and the calculated chemical formulae of the argentopentlandite from the Au-Ag-Cu mineralisation in the Paliomylos area.

\begin{tabular}{|c|c|c|c|c|c|c|c|c|c|c|c|c|c|c|c|}
\hline Wt: & 1 & 2 & 3 & 4 & 5 & 6 & 7 & 8 & 9 & 10 & 11 & 12 & 13 & 14 & AVG \\
\hline $\mathrm{Fe}$ & 37.40 & 37.70 & 37.20 & 36.85 & 36.71 & 37.20 & 35.96 & 37.46 & 36.38 & 37.25 & 36.65 & 36.25 & 36.15 & 36.30 & 36.82 \\
\hline $\mathrm{Ni}$ & 17.70 & 17.25 & 17.50 & 17.25 & 17.35 & 17.05 & 17.90 & 17.68 & 17.60 & 17.30 & 17.35 & 17.95 & 17.90 & 18.16 & 17.57 \\
\hline Co & bdl & 0.04 & bdl & 0.02 & 0.08 & 0.03 & 0.04 & 0.02 & bdl & bdl & 0.05 & bdl & bdl & 0.05 & 0.02 \\
\hline $\mathrm{Ag}$ & 13.35 & 12.78 & 12.97 & 12.88 & 13.05 & 13.15 & 13.50 & 12.88 & 12.90 & 13.05 & 13.35 & 13.30 & 13.50 & 13.50 & 13.15 \\
\hline $\mathrm{Au}$ & bdl & bdl & bdl & 0.65 & 0.55 & 0.45 & 0.65 & 0.68 & 1.59 & bdl & bdl & bdl & bdl & bdl & 0.33 \\
\hline Ir & bdl & bdl & 0.05 & bdl & bdl & bdl & bdl & bdl & 0.05 & 0.45 & 0.55 & 0.85 & 0.75 & 0.63 & 0.24 \\
\hline $\mathrm{Pd}$ & bdl & bdl & 0.05 & 0.05 & bdl & 0.05 & bdl & bdl & bdl & bdl & bdl & bdl & bdl & bdl & bdl \\
\hline Pt & bdl & bdl & bdl & 0.85 & 0.58 & 0.62 & 0.50 & bdl & bdl & 0.65 & 0.50 & bdl & bdl & 0.05 & 0.27 \\
\hline $\mathrm{Ru}$ & bdl & bdl & bdl & bdl & bdl & bdl & 0.05 & 0.05 & 0.05 & 0.05 & bdl & bdl & bdl & bdl & bdl \\
\hline $\mathrm{Rh}$ & bdl & 0.05 & bdl & bdl & bdl & bdl & bdl & 0.07 & bdl & bdl & bdl & bdl & bdl & bdl & $\mathrm{bdl}$ \\
\hline As & bdl & 0.06 & 0.25 & bdl & 0.22 & bdl & bdl & bdl & bdl & bdl & bdl & bdl & bdl & bdl & 0.04 \\
\hline $\mathrm{Cu}$ & 0.03 & 0.05 & bdl & bdl & 0.05 & bdl & bdl & 0.05 & bdl & bdl & bdl & bdl & bdl & 0.05 & bdl \\
\hline S & 31.38 & 31.51 & 31.45 & 31.49 & 31.48 & 31.62 & 31.46 & 31.35 & 31.45 & 31.08 & 31.15 & 31.15 & 31.20 & 31.10 & 31.35 \\
\hline Tot & 99.86 & 99.44 & 99.47 & 100.04 & 100.07 & 100.17 & 100.06 & 100.24 & 100.02 & 99.83 & 99.60 & 99.50 & 99.50 & 99.84 & 99.78 \\
\hline \multicolumn{16}{|c|}{ Chemical formulae } \\
\hline $\mathrm{Fe}$ & 5.50 & 5.54 & 5.48 & 5.44 & 5.43 & 5.47 & 5.32 & 5.50 & 5.38 & 5.51 & 5.44 & 5.37 & 5.36 & 5.38 & 5.44 \\
\hline $\mathrm{Ni}$ & 2.47 & 2.43 & 2.46 & 2.42 & 2.45 & 2.39 & 2.51 & 2.47 & 2.47 & 2.43 & 2.46 & 2.53 & 2.52 & 2.55 & 2.47 \\
\hline $\mathrm{Ag}$ & 1.01 & 0.97 & 1.00 & 0.98 & 1.00 & 1.00 & 1.03 & 0.99 & 0.99 & 1.00 & 1.02 & 1.02 & 1.04 & 1.03 & 1.01 \\
\hline $\mathrm{Au}$ & - & - & - & 0.03 & 0.02 & 0.02 & 0.03 & 0.03 & 0.07 & - & - & - & - & - & 0.01 \\
\hline Ir & - & - & - & - & - & - & - & - & - & 0.02 & 0.02 & 0.04 & 0.03 & 0.03 & 0.01 \\
\hline Pt & - & - & - & 0.04 & 0.02 & 0.03 & 0.02 & - & - & 0.03 & 0.02 & - & - & - & 0.01 \\
\hline$S$ & 8.02 & 8.06 & 8.06 & 8.09 & 8.08 & 8.09 & 8.09 & 8.01 & 8.09 & 8.01 & 8.04 & 8.04 & 8.05 & 8.01 & 8.05 \\
\hline
\end{tabular}

\section{FLUID INCLUSIONS}

Fluid inclusions were studied in double-polished thin sections, in order to estimate the temperature, pressure and composition of the fluids related to the formation of the investigated gold-bearing quartz veins and the associated mineralisation. Microscopic observations indicate two types of quartz, an older (Qz1) and a younger generation (Qz2). Qz1, which is the main carrier of the mineralisation, is related to the quartz segregations and pegmatoids and has been affected by the subsequent tectonic deformation, resulting in the recrystallisation of quartz and the destruction of its primary texture. Qz2 is undeformed and not related to the mineralisation and is associated to the the crosscuting quartz veins. Both generations of quartz contain only a few fluid inclusions suitable for thermometric measurements.

The studied fluid inclusions contain two phases: a liquid aqueous solution and a vapour bubble, which occupies 10 to $25 \%$ by volume and their size ranges between 3 and $15 \mu \mathrm{m}$. The homogenisation temperatures of the fluid inclusions hosted in Qz1, exceeds $400{ }^{\circ} \mathrm{C}$, and they are mainly above $600{ }^{\circ} \mathrm{C}$, which is the limit of the measurement ability of the LINKAM THM-600 stage. The freezing point of the Qz1 inclusions could not be measured, because of their small size. The temperatures of initial melting of inclusions in the undeformed Qz2 vary approximately from -19 to $-20^{\circ} \mathrm{C}$ indicating that the solutions consist mainly of $\mathrm{H}_{2} \mathrm{O}$ and $\mathrm{NaCl}$. Ice melting temperatures $\left(-12\right.$ to $\left.-7{ }^{\circ} \mathrm{C}\right)$ indicate salinities of 16 to $10.5 \mathrm{wt} \% \mathrm{NaCl}$ equiv. The homogenisation temperatures of these inclusions vary between 220 and $350^{\circ} \mathrm{C}$, with a maximum at $250{ }^{\circ} \mathrm{C}$.

\section{DISCUSSION}

The gold bearing quartz pegmatoids at Paliomylos area are of special interest due to the relatively high Au concentrations (up to $6.80 \mathrm{ppm}$ ), as well as to high silver content (up to $765 \mathrm{ppm}$ ). Gold is found as native with elevated $\mathrm{Ag}$ contents, while the main $\mathrm{Ag}$ carriers are hessite and argentopentlandite.

Argentopentlandite is a rare mineral and it has been described in only ten deposits worldwide, since it was first reported by Shishkin et al. (1971). Investigations on its occurrence, composition, structure and phase relations (Kontny et al. 1994, Morales and Fenoll Hach-Alv 1996, and references therein) revealed that it is a distinct mineral species, rather than a member of an isomorphous solid-solution series with pentlandite. Argentopentlandite from Paliomylos area is the second documented report of this mineral in Greece (Vavelidis 
et al. 2000). Previously, Mposkos (1983a,b) and Vavelidis et al. (1996) demonstrated the mode of occurrence and the chemistry of argentopentlandite from Koronouda $\mathrm{Cu}$-deposit, which is located about $10 \mathrm{~km}$ northwestern of Paliomylos area. Argentopentlanidite in Koronouda area is found in boudinaged quartz segregations and pegmatoids, intergrown with chalcopyrite and the $\mathrm{Ag}$ contents range between 11.95 and $13.40 \mathrm{wt} \%$ (12.76wt\% on average) corresponding to a chemical formula of $\mathrm{Fe}_{5.44} \mathrm{Ni}_{2.40} \mathrm{Ag}_{0.97} \mathrm{As}_{0.02} \mathrm{Au}_{0.01} \mathrm{Ir}_{0.01} \mathrm{Pt}_{0.01} \mathrm{~S}_{8.14}$ (Vavelidis et al. 1996). The present study confirms the similarities of the two Greek argentopentlandite occurrences concerning their mineralogical, textural and chemical features.

The Au-Ag-Cu bearing quartz segregations and pegmatoids are probably genetically associated with the adjacent granite of Arnea type, which occurs $5 \mathrm{~km}$ to the south (Figure 1). The emplacement of the Arnea granite took place during Late Triassic and was related to continental rifting (Kostopoulos et al. 2001). Christofides et al. (2000) and Kostopoulos et al. (2001) suggested that the Arnea granite is a high evolved granitic intrusion resulting from crustal anatexis.

The ascending magma of the granite was possibly the main source for the metals $\mathrm{Bi}, \mathrm{Pb}, \mathrm{As}, \mathrm{Zn}, \mathrm{Cu}, \mathrm{Ni}, \mathrm{Co}$, $\mathrm{Fe}, \mathrm{Te}, \mathrm{Au}$ and $\mathrm{Ag}$. Arnea granite is interpreted as crustal melt and hence it is considered that the surrounding host rocks could probably supply the magmatic system with basic and precious metals. This assumption is based also on the fact that the Vertiskos formation is enriched in base and precious metals and is considered to be the source for part of the gold and silver mineralisations in the Serbomacedonian massif (Vavelidis 1994, Vavelidis and Tarkian 1995, Vavelidis et al. 1996).

The structural analyses revealed that the quartz segregations and pegmatoids in Paliomylos area are syntectonic to the formation of metamorphic rocks. Papadopoulos and Kilias (1985) consider that the dominant schistosity of the metamorphic rocks is of Middle to Late Cretaceous age, whereas Kostopoulos et al. (2001) suggest an Early Cretaceous underthrusting of the Vertiskos sequence resulting in high pressure (11-14 kb) and temperature (500-600 ’IC) metamorphic rocks. For this event Sidiropoulos (1991) and Kourou (1991) reported metamorphic conditions of 500 to 640 ' IC and $>5.3 \mathrm{~kb}$ for the rock formations of the western Vertiskos group.

The metal-bearing quartz pegmatoids in the Paliomylos area were affected by the same tectonic phase, that also affected the host metamorphic rocks. As a result of that, the ore shows recrystallisation textures. This is also evidenced by the $\mathrm{Co} / \mathrm{Ni}$ ratio of pyrites (0.60-5.10), which is plotted in the field of the reformed ore deposits (Bralia et al. 1979).

The temperature of formation of the ore paragenetic assemblage is difficult to establish exactly. However, the determination of an interval of temperature is possible. Different events occurred within this interval. The characteristic inversion twins developed in chalcopyrite show that this mineral was formed at temperatures between 400 and $550{ }^{\circ} \mathrm{C}$ (Craig and Kullerud 1969). Argentopentlandite coexisting with chalcopyrite, has an upper stability limit at $455^{\circ} \mathrm{C}$, according to Mandzuik and Scott (1977). The most probable interval ranges from 400 to $550^{\circ} \mathrm{C}$. This interval is in accordance with the range in the temperature of homogenisation obtained from fluid inclusions of the quartz of first generation ( 400 to $>600{ }^{\circ} \mathrm{C}$ ). Kourou (1991) and Kostopoulos et al. (2001) suggested similar temperatures for the metamorphic rocks of the Vertiskos group.

Concerning gold formation, it is assumed that gold grains in pyrite, which are Ag-rich (17.26 wt \%), were crystallised during the first stages of the mineralisation. In contrast, gold grains in quartz are Ag-poor (2.71 wt $\%$ ) and they are interpreted to have been formed after the silver-bearing minerals, hessite and argentopentlandite, at the final mineralisation stage.

\section{CONCLUSION}

It is obvious that argentopentlandites from Paliomylos and Koronouda Cu-deposits display similar mineralogical and chemical features, giving the impression that these two deposits belong to the same metallogenetic zone in the Serbomacedonian massif. Based on the data published so far on Au-Ag-bearing Cu mineralisations hosted in quartz segregations in the metamorphic rocks of the Vertiskos series (Serbomacedonian massif), we could suggest that the metallogenetic zone extends in a NW-SE direction from Koronouda to Paliomylos area, with a possible extension to the more southern quartz-vein-associated Au-bearing deposits from Drakontio (Vavelidis et al. 1999) and Nea Madytos-Stanos area (Vavelidis and Tarkian 1995).

ACKNOWLEDGEMENTS: The first author (V. Melfos) would like to thank the State Scholarships Foundation of Greece for the financial support of the fluid inclusions study ( $1^{\text {st }}$ Project for Post-Doctoral Research). We also thank Dr. Dimitrios Kostopoulos (University of Thessaloniki) for his thorough and helpful comments on the manuscript, especially on the Geological Setting section. 


\section{REFERENCES}

BRALIA, A., SABATINI, G. AND TROJA, F. (1979). A revaluation of the Co/Ni ratio in pyrite as geochemical tool in ore genesis problems. Mineral. Deposita, 14, 353-374.

BURG, J.P., GODFRIAUX, I., RICOU, L.E. (1995). Extension of the Mesozoic Rhodope thrust units in the Vertiskos-Kerdilion massifs (Northern Greece). C. R. Acad. Sci. Paris, v.320, series IIa, 889-896.

CRAIG, J.R., KULLERUD, G. (1969). Phase relations in the Cu-Fe-Ni-S system and their application to magmatic ore deposits. Econ. Geol. Monogr., 4, 344-358.

CRISTOFIDES, G., KORONEOS, A., SOLDATOS, F., ELEFTHERIADIS, G. (2000). Mesozoic magmatism in the area between the Vardar (Axios) zone and the Serbomacedonian massif (Northern Greece). In: "Geology and Metallogeny of the Dinarides and the Vardar Zone", Banja Luka, Sarajevo. The Academy of Sciences and Arts of the Republic of SRDSKA. Collections and Monographs, Volume I, 111-120.

DE WET, A.P. (1989). Geology of part of the Chalkidiki Peninsula, northern Greece. Unpubl. Ph.D. thesis, University of Cambridge, U.K., 177 p.

DIXON, J.E. AND DIMITRIADIS, S. (1987).The metamorphic evolution of the Serbomacedonian Massif in Greece. Terra Cognita, 7, 106.

KIOURTZOGLOU, E., VAVELIDIS, M., SISMANIDIS, K. (2001). Metal objects' archaeometrical study from ancient Stagira. In: "The Archaeological Work in Macedonia and Thrace 2000" (in press).

KOCKEL, F., MOLLAT, H., WALTHER, H.W. (1977). Erlaeterungen zur geologischen Karte der Chalkdiki und angrenzenden Gebiete (Nord-Griechenland), 1:100.000. Bundesanst. Geowiss. Rohst., Hannover, 1 Karte in 4 Bloettern, 119p.

KONTNY, A., FRIEDRICH, G., HERZIG, P., KEYSSNER, S. (1994). Argentian-pentlandite-bearing assemblages in metamorphic rocks of the KTB pilot hole, Oberpfalz, Germany. Can. Mineral., 32, 803-814.

KOSTOPOULOS, D., REISCHMANN, T., SKLAVOUNOS, S. (2001). Palaeozoic and Early Mesozoic magmatism and metamorphism in the Serbomacedonian massif, Central Macedonia, Northern Greece. Jour. Conf. Abstracts of EUG 11, April 8-12 2001, Strasbourg (in press)

KOUROU, A. (1991). Lithology, tectonics, geochemistry and metamorphism of a part of the western Vertiskos group. The area NE from lake Koroneia. Unpubl. PhD thesis, Univ. of Thessaloniki, 461pp.

MANDZUIK, Z.L., SCOTT, S.D. (1977). Synthesis, stability, and phase relations of argentian pentlandite in the system Ag-Fe-Ni-S. Can. Mineral., 15, 349-364.

MORALES, S., FENOLL HACH-ALÍ, P. (1996). Hydrothermal argentopentlandite at El Carchón, Southeastern Spain: Mineral chemistry and conditions of formation. Can. Mineral., 34, 939-947.

MPOSKOS, E. (1983a). A mineralogical study of the Au-Ag-Bi-Te-Cu-Co-Ni-As-S ore mineralisation in Macedonia, Greece. Chem. Erde, 42, 281-296p.

MPOSKOS, E. (1983b). A new occurrence of argentian pentlandite from the Koronouda ore mineralisation, Macedonia, Greece. N. Jb. Miner. Mh., 5, 193-200.

PAPADOPOULOS, C. AND KILIAS, A. (1995). Alterbeziehugen zwischen Metamorphose und Deformation im zentralen Teil des Serbomazedonischen Massivs (Vertiskos Gebrige, Nord-Griechenland). Geol. Runds., 74, $77-85$.

RICOU, L. -E., BURG, J.P., GODFRIAUX, I., IVANOV, Z. (1998). Rhodope and Vardar: the metamorphic and the olistromatic paired belts related to the Cretaceous subduction under Europe. Geodinamica Acta, 11, 285309.

SAKELARIOU, D. (1989). Geologie des Serbomakedonischen Massivs in der nordoestlichen Chalkidiki, NGriechenland. Deformation und Metamorphose. Dokt. Arb. Univ. Mainz, 117p.

SHISHKIN, N.N., MITENKOV, G.A., MIKHAILOVA, V.A., RUDASHEVSKII, N.S., SIDOROV, A.F., KARPENKOV, A.M., KONDRAT'EV, A.V., BUD'KO, I.A. (1971). Pentlandite variety rich in silver. Zap. Vses. Mineral. Obshcest., 100, 184-191.

SIDIROPOULOS, N. (1991) Lithology, tectonics, geochemistry and metamorphism of northwestern part of the Vertiskos group. The area of Kroussia mountain north from Kilkis. PhD Thesis, Univ. of Thessaloniki, 592pp.

VAVELIDIS, M. (1994). Au-Ag-bearing mineralisations in the Serbomacedonian massif, Northern Greece. Beih. zum Eur. Jour. Miner., 6, 292.

VAVELIDIS, M., TARKIAN, M. 1995. Mineralogy of the gold-silver-bearing copper mineralised zones in the Paliopyrgos (Nea Madytos-Stanos) area, Northern Greece. N. Jb. Miner. Mh., 3: 133-143.

VAVELIDIS M., KILIAS A., MELFOS V., SCHMIDT-MUMM A. (1996). New investigations in the Au-Agbearing $\mathrm{Cu}$ mineralisation in the Koronouda area, Central Macedonia, Northern Greece. In: Terranes of Ser- 
bia. The Formation of the Geologic Framework of Serbia and the Adjacent Regions. Eds. Knezevic \& Krstic, 317-322.

VAVELIDIS, M., MELFOS, V., KILIAS, A. (1999). The gold-bearing quartz veins in the metamorphic rocks at the Drakontio area, central Macedonia, northern Greece. In: Mineral Deposits: Processes to Processing (ed: C.J. Stanley et al.) 209-212.

VAVELIDIS, M., MELFOS, V., ARIKAS, K. (2000). Mineralogy and structural control of the Ag-rich copper mineralization in the Serbomacedonian massif, Paliomylos area, Greece. Beih. zum Eur. Jour. Miner., 12, 220.

VITAL, C. (1986). Mineralogical and petrographical investigations of the area between Arnea and Megali Panagia, Chalkidiki peninsula (northern Greece). Unpubl. PhD thesis, ETH Zürich, 125 p.

WAGNER G.A., PERNICKA E., VAVELIDIS M., BARANYI I., BASSIAKOS I. (1986). Archaeometallurgische untersuchungen auf Chalkidiki. Anschnitt, 38, 166-186. 